\title{
Fish activity: a major mechanism for sediment resuspension and organic matter remineralization in coastal marine sediments
}

\author{
Gitai Yahel ${ }^{1,6, *, * *}$, Ruthy Yahel ${ }^{1,2, * *}$, Timor Katz $^{3,4, * *}$, Boaz Lazar $^{3}$, Barak Herut ${ }^{4}$ \\ Verena Tunnicliffe ${ }^{1,2,5}$ \\ ${ }^{1}$ Department of Biology, University of Victoria, PO Box 3020, Victoria, British Columbia V8W 3N5, Canada \\ ${ }^{2}$ VENUS, University of Victoria, PO Box 1700, Victoria, British Columbia V8W 2Y2, Canada \\ ${ }^{3}$ The Institute of Earth Sciences, The Hebrew University, Givat Ram, Jerusalem 91904, Israel \\ ${ }^{4}$ Israel Oceanographic and Limnological Research, Haifa 31080, Israel \\ ${ }^{5}$ School of Earth \& Ocean Sciences, University of Victoria, PO Box 3055, Victoria, British Columbia V8W 3P6, Canada
}

${ }^{6}$ Present address: School of Marine and Environmental Science, Michmoret 40297, Israel

\begin{abstract}
We quantify sediment resuspension due to groundfish activity in a partly anoxic basin using acoustic backscatter sensors, transmissometers, and remotely operated cameras on stationary and mobile platforms. Where these fish were present, a distinct benthic nepheloid layer (BNL) developed despite minimal bottom currents $\left(<10 \mathrm{~cm} \mathrm{~s}^{-1}\right)$. In contrast, water clarity was markedly higher over the adjacent anoxic and fishless zone. Sediment resuspension events, mostly by flatfish, occurred at a rate of $>100$ disturbances $\mathrm{m}^{-2} \mathrm{~d}^{-1}$ resulting in complete surface reworking every $2.5 \mathrm{~d}$ and a daily resuspension of $1.3 \pm 0.7 \mathrm{l}$ bulk sediment $\mathrm{m}^{-2} \mathrm{~d}^{-1}$. Preliminary geochemical measurements suggest substantial impact of fish resuspension activity, the immediate effect being an instantaneous increase in nutrient concentration in the benthic boundary layer and a drop in oxygen concentration. Over longer time scales (hours to days), the freshly exposed organic matter is oxidized and additional nutrients (silica, ammonium, phosphate) are regenerated and released to the water. The increase in benthic oxygen demand suggests that fish activity reduces organic carbon sequestration by $9 \pm 5 \mathrm{mmol} \mathrm{C} \mathrm{m}^{-2} \mathrm{~d}^{-1}$, equivalent to $\sim 40 \%$ of its downward flux in this basin. To date, these processes are missing from geochemical models and require further investigation, particularly considering the depletion of groundfish stocks and the likely effects on global biogeochemical cycles.
\end{abstract}

KEY WORDS: Bioturbation · Benthic-pelagic coupling · Sediment geochemistry $\cdot$ Carbon sequestration $\cdot$ Flatfish $\cdot$ Saanich Inlet

\section{INTRODUCTION}

A key determinant of ocean productivity is the exchange of essential nutrients across the sediment-water interface. The ocean floor is a major sink for photosynthetically fixed carbon and biogeochemically important elements such as N, P, Fe, and Si (Hedges \& Keil 1995). The fate of these elements in marine sediments is controlled mainly by exposure to oxygen (Hartnett et al. 1998) and by regeneration and trans- port processes (Rutgers van der Loeff et al. 2002). Much of marine primary production and $90 \%$ of organic matter burial occur in continental margins (Table 6.5.1 in Sarmiento \& Gruber 2006) of which $>10 \%$ takes place in temperate fjords and inlet systems (Nuwer \& Keil 2005). Over $80 \%$ of seafloor remineralization occurs on the continental shelf and nutrient regeneration from sediments provides up to half the uptake by phytoplankton in coastal waters (Jorgensen 1983). Therefore, processes controlling mass 
transfer, burial, and regeneration of nutrients and other compounds in marine sediments have a major influence on global biogeochemical cycles.

In high-energy habitats; waves and currents dominate sediment resuspension dynamics and, therefore, also mass transfer processes from the sediment to the overlying water (Stahlberg et al. 2006) and ultimately, sediment geochemistry and composition (Sarmiento \& Gruber 2006). However, even in relatively shallow coastal seas, physical resuspension is a rare event and bottom areas deeper than 50 to $60 \mathrm{~m}$ are often unaffected by physical forcing (Danielsson et al. 2007). In calm, deep coastal habitats, organic matter thus accumulates and other processes such as molecular diffusion and bioturbation by invertebrates living in the sediment (Meysman et al. 2006) are believed to control sediment transformation and mass flux across the sediment-water interface (Berner 1980, Aller \& Aller 1998).

Benthic nepheloid layers (BNL) are the lower sections of the water column where the amount of suspended sediment is high. BNLs cover vast areas of the ocean floor, particularly over the continental margins (McCave 1986, McCave et al. 2001), and are characterized by enhanced bacterial activity and organic matter remineralization (Boetius et al. 2000). While BNLs are maintained by water turbulence in high-energy marine environments, the mechanisms that maintain them in low-energy marine environments are not yet identified (e.g. Hales et al. 2006).

Nutrient concentrations and algal biomass are often controlled by bottom fish in shallow lakes (Meijer et al. 1990, Scheffer et al. 2003) and the digging activity of spawning salmon may account for approximately half of the sediment transport in a given stream (Hassan et al. 2008). In coral reefs, we showed that benthic fish also control sediment resuspension (Yahel et al. 2002). Benthic fish that resuspend sediment as they search for food and shelter are abundant throughout the ocean. Unlike other resuspension processes, fish induced resuspension events are typically brief (seconds) and localized (Yahel et al. 2002). However, the contribution of benthic fish activity to sediment resuspension and nutrient recycling is barely reported in marine systems.

In this study, we tested the hypothesis that the resuspension activity of fish can play a significant role in mass transfer processes from marine sediments. The control that fish activity exerts on the extent of BNLs was examined in Saanich Inlet where bottom-water anoxia creates adjacent zones with and without fish. Anoxia in sediments precludes occupancy by benthic fauna that could rework the deposits (Gucluer \& Gross 1964, Tunnicliffe 2000). Fish activity and sediment resuspension rates were quantified in situ using a range of complementary techniques. Auxiliary experi- ments were done to test the potential effects of fish resuspension activity on benthic oxygen demand and on fluxes of essential elements across the sedimentwater interface.

\section{MATERIALS AND METHODS}

Our work was conducted in conjunction with the installation and initial operation phase of the VENUS cabled undersea observatory (www.venus.uvic.ca). After a pilot study in November 2004, our fieldwork occurred in July 2005 and February 2006 onboard the CCGS 'J. P. Tully' using the remotely operated vehicle (ROV) ROPOS (www.ropos.com) to conduct the underwater work.

Study site. Saanich Inlet (British Columbia, Canada, Fig. 1) is a highly productive northeast Pacific fjord, penetrating $40 \mathrm{~km}$ from the Strait of Georgia into Vancouver Island; the $230 \mathrm{~m}$ deep basin is separated from the Strait by a $65 \mathrm{~m}$ deep sill. The Inlet is intermittently anoxic with near to total anoxic conditions below $\sim 120 \mathrm{~m}$ depth due to strong stratification of the water column and restricted deepwater circulation (Anderson \& Devol 1973). Sediment characteristics are described in detail by Gucluer \& Gross (1964).

The study site lies in a large bay where a silty bottom underlies the transition from anoxic to hypoxic to oxygenated water upslope from 180 to $60 \mathrm{~m}$ (Fig. 1). Juxtaposition of oxygenated and anoxic habitats allows comparison of sediment conditions with and without benthic fish (Fig. 2). The restricted basin has little deep wave or bottom current action (Gargett et al. 2003). Instrument packages were deployed in 3 sites $<500 \mathrm{~m}$ apart: (1) an oxic site (dissolved oxygen [DO] concentration $>1.75 \mathrm{ml} \mathrm{l}^{-1}, 78 \mu \mathrm{mol} \mathrm{l^{-1 }}$ ) at $95 \mathrm{~m}$ with infauna present, bioturbation, no bacterial mats, and abundant epifauna (fish and crustaceans); (2) a hypoxic site $(0.5$ $\mathrm{ml} \mathrm{l}^{-1}<\mathrm{DO}<0.9 \mathrm{ml} \mathrm{l}^{-1}$ ) at $102-105 \mathrm{~m}$ with poorly consolidated sediment, rare infauna, bioturbation, intermittent bacterial mats, and abundant epifauna; and (3) a near-anoxic site (DO $<0.1 \mathrm{ml} \mathrm{l}^{-1}, 4 \mu \mathrm{mol} \mathrm{l} \mathrm{l}^{-1}$ ) at $135 \mathrm{~m}$ with soupy sediments, no infauna, rare epifauna, little bioturbation, and extensive bacterial mats.

Chemical and physical conditions. Using the ROV ROPOS, we placed packages of instruments to monitor resuspension events in the 3 locations: oxic, hypoxic and near anoxic (the soupy sediment in the truly anoxic zone did not permit deployment of bottommounted instruments; Table 1). Important instruments were transmissometers and acoustic doppler current meters (Aquadopp, Nortek), both mounted with beams parallel to the bottom to detect upward-moving sediments. The third tool was a remotely operated camera on the VENUS observatory that allowed a shore-side 




Fig. 1. Study site at Saanich Inlet, Vancouver Island, BC, Canada. Light gray shading indicates the extent of the anoxic zone, $\boldsymbol{\nabla}$ is the location of the VENUS camera and the dotted line shows the path of the video transect for fish abundance. Inset shows the location of Saanich Inlet (black arrow) in Vancouver Island off the west coast of Canada

observer to activate lights and record bottom activity with video and still image records. In November 2004 and July 2005, the instrument packages recorded a short time series of acoustic backscatter and transmissivity (both proxies for suspended sediment concentrations) along with ancillary near-bottom currents,

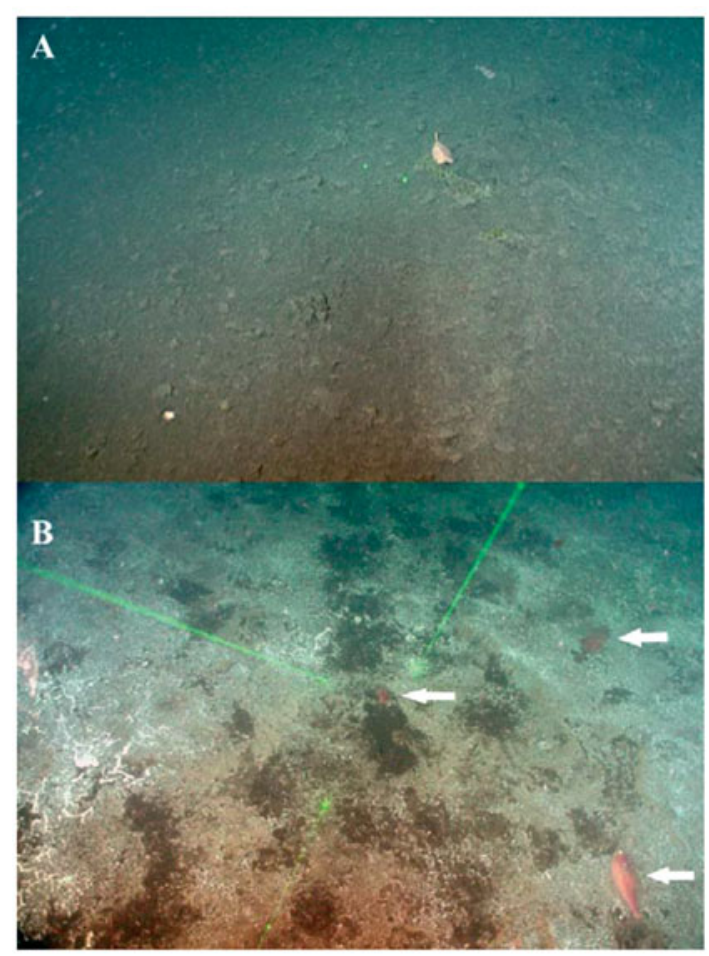

Fig. 2. Sediments in Saanich Inlet, British Columbia, Canada: (A) intact, in anoxic water at $159 \mathrm{~m}$ depth; and (B) reworked, in hypoxic water at $127 \mathrm{~m}$ depth. Both images were taken in July 2005 along the transect indicated in Fig. 1. A leaf lies in the center of (A). Three slender sole Lyopsetta exilis, 2 partially buried in the sediment, are indicated by the white arrows in (B). The white material on the sediment is a filamentous bacterial mat that grows in hypoxic conditions

oxygen, temperature, pressure, and salinity. Table 1 reports deployment details. A continuous time series of these and additional parameters is now recorded at our study site (starting February 2006) by the cabled VENUS underwater observatory. These data are available at www.venus.uvic.ca.

To measure the spatial variation in near-bottom conditions, we equipped the ROV with an online instrument package (Yahel et al. 2007) that included a pumping CTD (SBE 19plus, SeaBird), an oxygen sensor (SBE 43), a transmissometer $(25 \mathrm{~cm}$, CStar, WetLabs), and a chlorophyll fluorometer (WETStar, WetLabs). System intake was through a $30 \mathrm{~cm}$ tube positioned atop the ROV, $\sim 2 \mathrm{~m}$ above bottom (mab). Samples to determine vertical profiles of water properties were also collected using standard shipboard bottle casts with Go-Flow bottles (General Oceanic).

Quantifying fish abundance. Fish abundance was estimated along video transects from the middle of the inlet (190 m) to Patricia Bay (60 to 90 m, Fig. 1). ROPOS, equipped with a colour video camera (DXC 990, Sony) and powerful white lights $(7 \times 250 \mathrm{~W})$, travelled along 
Table 1. Instruments deployed in Saanich Inlet to measure sediment resuspension events and fish activity. Each Aquadopp acoustic current meter was mounted with 2 beams parallel to the seafloor, allowing concurrent assessment of current and suspended sediment concentration. The transmissometer beams, also parallel to the bottom, measured light attenuation at $680 \mathrm{~nm}$. Since February 2006, online data have been made available through the VENUS underwater-cabled observatory (www.venus.uvic.ca)

\begin{tabular}{|c|c|c|c|c|c|c|c|c|}
\hline $\begin{array}{l}\text { Depth } \\
\text { zone }(\mathrm{m})\end{array}$ & $\begin{array}{l}\text { Instrument } \\
\text { package }\end{array}$ & Date & $\begin{array}{l}\text { Duration } \\
\text { (d) }\end{array}$ & $\begin{array}{l}\text { Sampling } \\
\text { interval } \\
\text { (s) }\end{array}$ & $\begin{array}{l}\text { Sampling } \\
\text { duration } \\
\text { (s) }\end{array}$ & $\begin{array}{l}\text { No. of } \\
\text { beams }\end{array}$ & $\begin{array}{l}\text { Beam } \\
\text { length } \\
(\mathrm{m})\end{array}$ & Comments \\
\hline \multicolumn{9}{|l|}{ Oxic } \\
\hline \multirow[t]{2}{*}{95} & $\begin{array}{l}\text { Aquadopp (Nortek) } \\
\text { PLUS }\end{array}$ & $\begin{array}{l}6-17 \\
\text { July } \\
2005\end{array}$ & 10.9 & 10 & 2 & 2 & 1.0 & $\begin{array}{l}\text { Ancillary CTD (SBE 16, } \\
\text { Seabird) and oxygen } \\
\text { Optode (Aanderaa) }\end{array}$ \\
\hline & $\begin{array}{l}\text { Transmissometer } \\
\text { (Seatech) }\end{array}$ & & 7.5 & 10 & 1 & 1 & 0.25 & \\
\hline \multicolumn{9}{|l|}{ Hypoxic } \\
\hline \multirow[t]{2}{*}{102} & $\begin{array}{l}\text { VENUS Camera } \\
\text { (Cyclops, CMap) }\end{array}$ & $\begin{array}{l}25 \text { April- } \\
21 \text { May } 2006\end{array}$ & 26 & Variable & 180 & $2^{\mathrm{a}}$ & $0.87^{\mathrm{a}}$ & $\begin{array}{l}\text { Operated remotely; } \\
57 \text { video clips collected }\end{array}$ \\
\hline & Aquadopp & $\begin{array}{l}7 \text { February- } \\
11 \text { May } 2007\end{array}$ & 82 & 600 & 600 & 2 & 1.0 & $\begin{array}{l}\text { Ancillary CTD (SBE 16, } \\
\text { Seabird) and oxygen } \\
\text { Optode (Aanderaa) }\end{array}$ \\
\hline 105 & $\begin{array}{l}\text { Transmissometer } \\
\text { (CStar, Wet Labs) }\end{array}$ & $\begin{array}{c}9-14 \\
\text { November } \\
2004\end{array}$ & 5.5 & 18 & 1 & 1 & 0.25 & $\begin{array}{l}\text { Ancillary CTD (SBE 16, } \\
\text { Seabird) }\end{array}$ \\
\hline \multicolumn{9}{|c|}{ Near anoxic } \\
\hline \multirow[t]{2}{*}{135} & $\begin{array}{l}\text { Aquadopp (2 MHz, } \\
\text { Nortek) PLUS }\end{array}$ & $\begin{array}{l}\text { 6-17 July } \\
2005\end{array}$ & 7.6 & 10 & 2 & 2 & 1.0 & $\begin{array}{l}\text { Ancillary temperature, } \\
\text { and pressure }\end{array}$ \\
\hline & $\begin{array}{l}\text { Transmissometer } \\
\text { (CStar, Wet Labs) }\end{array}$ & & 7.6 & 10 & 1 & 1 & 0.25 & \\
\hline
\end{tabular}

1.2 to $1.5 \mathrm{mab}$ at an average speed of $14 \pm 10 \mathrm{~cm} \mathrm{~s}^{-1}$ with the camera fixed at $\sim 45^{\circ}$ towards the bottom. Two parallel laser pointers $10 \mathrm{~cm}$ apart were used to scale the transect width $(1.2 \pm 0.2$ and $1.0 \pm 0.1 \mathrm{~m}$ in July 2005 and February 2006, respectively). Fish counts are most likely underestimates due to low visibility in the shallower parts of the inlet and undetected fish buried in sediments (e.g. Fig. 2B) (Spencer et al. 2005; we did not use a tickler chain). In contrast to other fish like the walleye pollock Theragra chalcogramma, flatfish (the majority of the fish in our site) did not seem to be affected by the ROV lights. An ultra-short baseline navigation system on ROPOS provided positioning and track length accuracy of $\pm 1 \mathrm{~m}$. Fish for taxonomic and morphometric analyses were collected using an otter trawl in February 2005 (70 m) and July 2005 (90 m).

Quantifying fish resuspension activity. The rate of occurrence of brief resuspension events was estimated either simultaneously or separately using 3 complementary methods (Table 1): (1) Measurement of the frequency of abrupt elevations in near-bottom acoustic backscatter (a proxy for suspended sediment concentration) using acoustic doppler current meters (2 $\mathrm{MHz}$ Aquadopp, Nortek) concurrently with nearbottom current measurements. The narrow acoustic beams of the instruments (two $1 \mathrm{~m}$ long beams for each Aquadopp) were oriented parallel to the bottom at 0.3 to 1 mab; (2) Similar measurement of the rate of abrupt elevations in turbidity (decrease of light transmission) using transmissometers with their $25 \mathrm{~cm}$ light path oriented horizontally at 0.1 to $1 \mathrm{mab}$; and (3) Direct observations of fish behaviour, fish abundance, and fish induced resuspension events with the VENUS real-time underwater video camera. Three min video clips were taken haphazardly during both day and night. Care was taken not to exceed 3 clips or a total of 10 min illumination time $\mathrm{d}^{-1}$ to minimize the effect of camera lights on fish behaviour. Our observations with both ROPOS and the VENUS camera indicate that $>90 \%$ of fish movements on the bottom caused resuspension (e.g. video clip 1, available as MEPS Supplementary Material at: www.int-res.com/articles/suppl/ m372p195_app/). In fact, for the flatfish that dominates the benthic fish community, each excursion to the water column resulted in 2 resuspension events, 
one upon emergence, and the other when the fish reburied itself (e.g. video clip 2, available at www.int-res. com/articles/suppl/m372p195_app/). Thus, any fish intersection with the acoustic beams (seen as intense reflectors) was considered as a resuspension event.

Assessing potential effects of fish-induced resuspension. To estimate the potential geochemical consequence of sediment resuspension by fish, we sampled and compared features of the near-bottom water before and after sediment resuspension by fish. We also performed in situ and in vitro simulations of fish induced resuspension events with Saanich Inlet sediment.

Sampling fish-induced sediment clouds: To measure the effect of brief resuspension events on the water column, we used a newly developed point water sampler, the 'SIP' (Fig. 3), which is a Teflon-coated sample cylinder (150 ml) equipped with 2 valves (Yahel et al. 2007). Prior to sampling, SIPs were acid washed, flushed with helium to remove air and water residues, and evacuated by ultra vacuum $(<0.67 \mathrm{mPa})$. Triggering the SIP valve by the ROV manipulator initiated a strong suction of the sample water into the SIP. A pair of SIPs, held together on a frame, was carefully positioned next to a flatfish lying on the bottom. One of the samplers was triggered in the ambient water above the fish. When the fish moved, it created a brief resuspen-
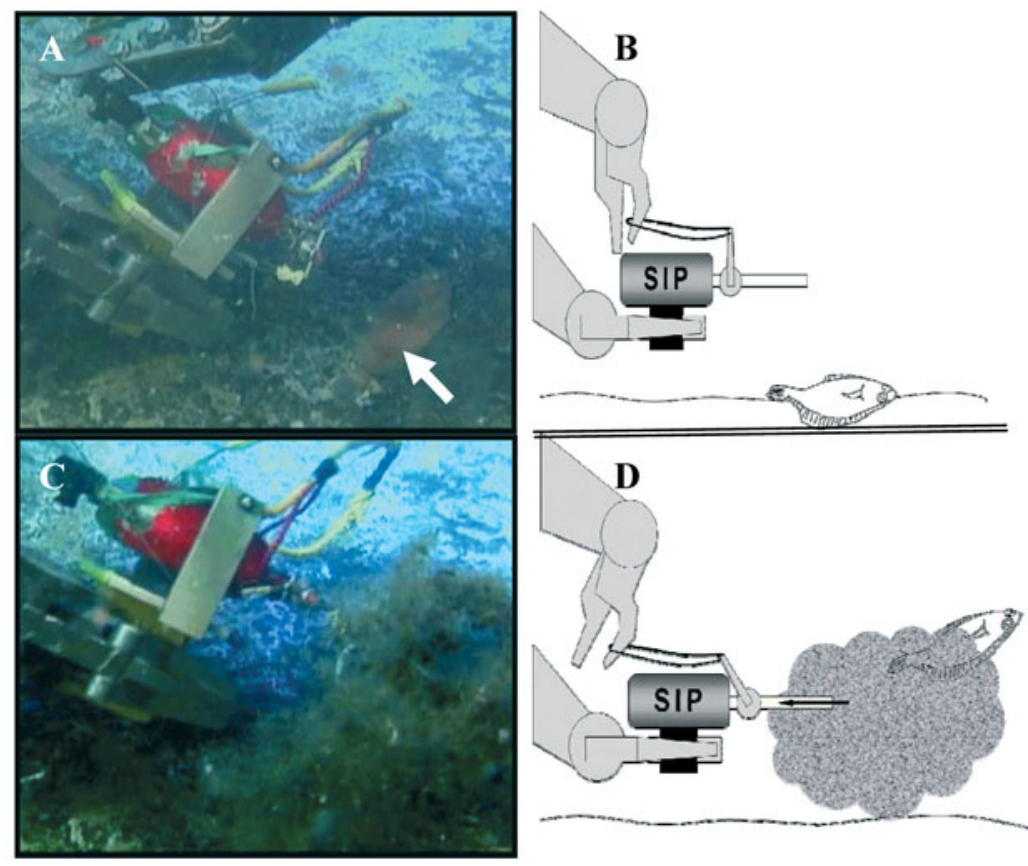

Fig. 3. Sampling a fish-induced resuspension cloud using the robotic manipulators of the ROV ROPOS and the SIP sampler. $(\mathrm{A}, \mathrm{B})$ Positioning of the SIP intake just above a resting slender sole Lyopsetta exilis (white arrow in A) and waiting for it to move and resuspend sediment. $(\mathrm{C}, \mathrm{D})$ Sampling the water from the sediment cloud immediately after resuspension by the emerging fish. The robotic arm pulls open the SIP sampler valve to initiate water suction into the SIP. See also video clip 3 sion event or a 'cloud' of sediments and the second SIP was triggered within that cloud (Fig. 3c,d; video clip 3, available at www.int-res.com/articles/suppl/ m372p195_app/). Due to bottom time constraints, only 13 paired samples were collected, of which 10 were successfully triggered. Water samples inside the SIPs were incubated at bottom conditions for 4 to $9 \mathrm{~h}$ during the remainder of the dive. Once onboard, the sampled water was cleanly filtered on pre-combusted GF/F filter. A $40 \mathrm{ml}$ aliquot of the filtrate was immediately analyzed for ammonium. Two $12 \mathrm{ml}$ duplicates were rozen for analyses of nitrate, nitrite, phosphate, and silicic acid (see below).

Simulating resuspension in a benthic chamber: To study short-term dynamics following a brief resuspension event, a PVC cylinder (19 cm inner $\varnothing, 31 \mathrm{~cm}$ high) was inserted by ROPOS into the sediment $(10 \mathrm{~cm}$ to a stop collar) enclosing an area of $0.03 \mathrm{~m}^{2}$ at $96 \mathrm{~m}$ depth (17 July 2005). The next day, ROPOS fitted a watertight lid on the cylinder. Light transmission, salinity, and temperature were monitored in real time by connecting 2 ports on the lid to the inlet and outlet of the instrument package installed on ROPOS, thus forming a closed circuit. This setup also insured rapid but mild mixing of the chamber water. Available ROV time allowed only 25 min to measure the oxygen demand of undisturbed sediment with a closed lid. A brief but strong water jet was then applied toward the bottom inside the chamber (100 ml, $5 \mathrm{~s}$ by a hydraulic syringe) to simulate the abrupt sediment resuspension induced by fish. Discrete water samples were drawn through $1 \mathrm{~m}$ PEEK tubing ( $1 \mathrm{~mm}$ internal $\varnothing$ ) attached individually to 6 SIP samplers. Three samples were collected at 3,12, and 21 min prior to the resuspension simulation and another three at 2, 8, and 13 min after the brief resuspension. To replenish the water withdrawn by the sampling, a latex balloon was secured inside the lid and connected to a port that was open to the ambient water. Major drawbacks of the in situ simulation were its short duration and the lack of control of the resuspension magnitude. Once onboard, water samples from the SIPs were processed as described above.

Simulating resuspension in an onboard incubator: To estimate the potential long-term effect of fish induced resuspension on benthic oxygen demand, we used ROPOS to collect undisturbed surface sediments with small acrylic push corers $(4.5 \mathrm{~cm}$ inner $\varnothing$, 
$30 \mathrm{~cm}$ long). Three cores (15.1 $\pm 1.4 \mathrm{~cm}$ length) were collected at $96 \mathrm{~m}$ depth for Incubation Expt 1 (February 2006) and 4 cores $(16.7 \pm 1.3 \mathrm{~cm})$ were collected $2 \mathrm{~d}$ later at 96 to $105 \mathrm{~m}$ depth for Incubation Expt 2. Cores were placed vertically in a sealed compartment (20 $\mathrm{cm} \varnothing, 36.5 \mathrm{~cm}$ high) of a double-walled cylindrical incubator filled with bottom water collected from the same site with Go-Flow bottles. Each experiment consisted of 3 stages: plugged core incubation (control, $1.5 \mathrm{~h}$ ), open core incubation (undisturbed sediment, $4.5 \mathrm{~h}$ ), and after brief resuspension event simulation $(>24 \mathrm{~h})$.

Once all bubbles were removed, an overlying water compartment was filled with the same bottom water. Temperature in the incubator was kept at $7 \pm 1^{\circ} \mathrm{C}$ ( 2 to $3^{\circ} \mathrm{C}$ lower than bottom temperature) by pumping seawater through the sleeve. A peristaltic pump insured gentle mixing $\left(20 \mathrm{ml} \mathrm{min}^{-1}\right)$ of the sealed compartment water. Benthic oxygen demand was monitored by siphoning the sealed compartment water into $125 \mathrm{ml}$ Winkler bottles allowing at least one bottle volume to overflow into an acid washed container. To replenish the volume lost during sampling, a unidirectional valve allowed water from the overlying compartment to flow into the sealed chamber. Therefore, oxygen and nutrient samples of the overlying water were collected after each sampling of the chamber.

Resuspension was simulated by mixing $31.8 \mathrm{ml}$ of the surface sediment (the upper $2 \mathrm{~cm}$ of one core) in the sealed chamber $(2 \mathrm{~cm}$ is approximately the depth of a buried flatfish). Based on dry sediment density of $2.82 \mathrm{~g} \mathrm{ml}^{-1}$ (Gucluer \& Gross 1964), measured surfacesediment water content of 79 and $55 \%$ for Expts 1 and 2 , and respective porosity of 0.93 and 0.79 , we calculated respective resuspension of 7.2 and $19.0 \mathrm{~g}$ dry matter. The water in the sealed compartment remained visibly turbid for the first $7 \mathrm{~h}$ of the first experiment and for $4 \mathrm{~h}$ of the second experiment.

Nutrient and dissolved oxygen analysis: Ammonium was analyzed onboard within $4 \mathrm{~h}$ of collection according to the fluorometric method for sub-micromolar concentrations (Holmes et al. 1999). Nitrate, nitrite, phosphate, and silicic acid were analyzed at the InterUniversity Institute of Eilat, Israel. Phosphate was measured using the molybdenum blue method modified for analysis with a Quick Chem 8000 flow injection nutrient analyzer (Lachat Instruments) (Fuller et al. 2005). Nitrate and nitrite were measured as described by Lindell \& Post (2001). Dissolved silicic acid was measured using the molybdate blue spectrophotometric method (Strickland \& Parsons 1972) modified for analysis with a Quick Chem 8000 flow injection nutrient analyzer. Dissolved oxygen samples were collected into $125 \mathrm{ml}$ Winkler bottles and analyzed within $48 \mathrm{~h}$ using Winkler titration at the Institute of Ocean Sci- ences (Sidney, BC, Canada). Our analytical precision was better than $\pm 1 \%$ for all analyses except for the low oxygen measurements.

Statistical analysis. Statistical analysis was carried out using SPSS 12.0 for Windows. To calculate the rate of resuspension events, we used only resuspension events that created large sediment clouds reaching $>0.5$ mab (e.g. the last events in video clips $1 \& 2$ ). Video observations suggest that these events normally occurred when flatfish emerged from or buried into the sediment. To estimate the frequency and duration of brief resuspension events, we calculated the $99 \%$ prediction interval around the local central tendency measure (calculated as moving median, moving average, or prior moving average) using 60 or 100 min windows along the time series. Values exceeding the prediction interval were considered resuspension events. An uninterrupted sequence of values exceeding the prediction interval was deemed a single resuspension event. Comparison of the different smoothing parameters yielded similar results $( \pm 20 \%$ of the $60 \mathrm{~min}$ moving average) for both the 135 and the $95 \mathrm{~m}$ deep stations. For subsequent analysis, we used a $60 \mathrm{~min}$ moving median (360 data points) as our central tendency measure and deviations from the upper $99 \%$ prediction interval as our criteria for major resuspension events. No similar outliers were detected when a transmissometer was deployed in a running seawater tank with Saanich Inlet sediment but no fish. All results were normalized for a $1 \mathrm{~m}^{2}$ area assuming a $0.5 \mathrm{~m}$ detection area from each side of the acoustic or optical beams.

Nutrient concentrations obtained with the SIPs were compared using a doubly repeated measured ANOVA with the 4 nutrients as 'measured' and the ambient and 'in cloud' concentrations as 'repeated measures'.

\section{RESULTS}

\section{Chemical and physical setting}

Below $50 \mathrm{~m}$, the conditions in Saanich Inlet are stable with an annual temperature range of 8 to $10^{\circ} \mathrm{C}$ and annual salinity range of 30.4 to 31.4 . Bottom currents are slow $\left(<16 \mathrm{~cm} \mathrm{~s}^{-1}\right)$ with average speed of $3.6 \pm 2.1 \mathrm{~cm} \mathrm{~s}^{-1}$ (measured at $102 \mathrm{~m}$ depth with a $2 \mathrm{MHz}$ Aquadopp, February 2007 to March 2008, 1 mab). Despite the slow bottom currents, a developed BNL extended to about 20 mab over the oxygenated margins of the Inlet. This layer is characterized by opposing steep gradients of dissolved oxygen and phosphate (Fig. 4). The apparent oxygen utilization (AOU, $140 \mathrm{\mu mol} \mathrm{l}^{-1}$ ) and the corresponding $1 \mu \mathrm{mol} \mathrm{l^{-1 }}$ increase in phosphate within the BNL suggests intense decomposition on the bottom 

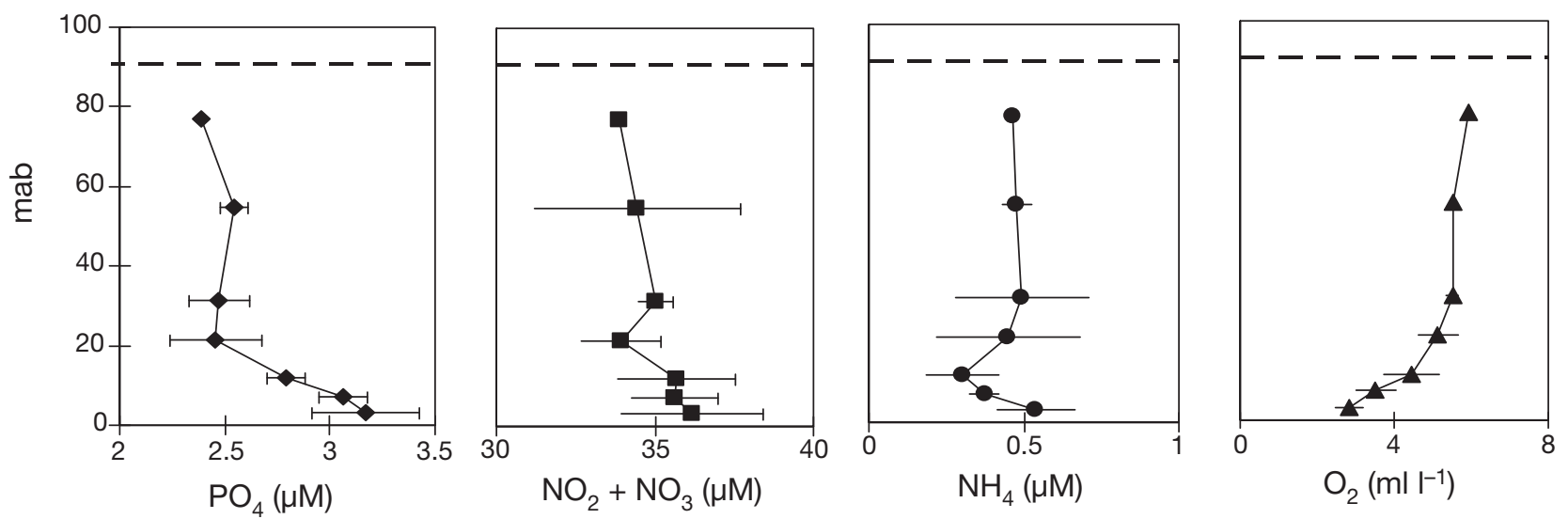

Fig. 4. Vertical profiles of nutrient concentrations and dissolved oxygen (February 2006) above the oxic study site as a function of distance from the bottom. Data are means \pm SD of 3 Go-Flow casts taken at 86,92 , and $94 \mathrm{~m}$ depth. $y$-axis in meters above bottom (mab); dashed line indicates sea surface

(Redfield et al. 1963, Anderson 1995). During the observation period (Table 1), the near-bottom currents did not exceed $10 \mathrm{~cm} \mathrm{~s}^{-1}$ (95 m deep, $1 \mathrm{mab}$ ) and nearbottom light transmissivity was normally $>70 \%$ although brief spikes down to zero transmissivity were common (see below). The surface sediment (down to $2 \mathrm{~cm}$ ) in the oxic site was olive green in color with only slight odor of sulfide. Organic carbon and nitrogen contents ranged from 1 to $3.5 \%$ and from 0.15 to $0.45 \%$, respectively, with a relatively constant $\mathrm{C} / \mathrm{N}$ ratio of $9.3 \pm$ 0.7 . The average porosity $(\phi)$ of surface sediments was $0.79 \pm 0.10$ (range 0.65 to 0.96 ), with water content of $53 \pm 13 \%$ (range 38 to $80 \%$ ) and average solids content of $0.84 \pm 0.14 \mathrm{~g}$ dry wt $\mathrm{ml}^{-1}$.

\section{Fish abundance and distribution}

The benthic fish community in Saanich Inlet is dominated by small flatfish, mostly slender sole (Pleuronectidae: Lyopsetta exilis) in deeper water and $L$. exilis mixed with English and rock sole (Parophrys vetulus and Lepidopsetta sp., respectively) at shallower depths. Densities averaged $0.5 \pm 0.4$ ind. $\mathrm{m}^{-2}$ at 90 to $120 \mathrm{~m}$ depth in July 2005 (Fig. 5A) and $1 \pm 0.8$ ind. $\mathrm{m}^{-2}$ at 60 to $120 \mathrm{~m}$ depth in February 2006 (Fig. 5B). During installation and maintenance of the VENUS observatory (2003 to 2007), we observed similar fish densities in numerous ROPOS dives throughout the oxygenated zone ( 60 to $120 \mathrm{~m}$ depth). Sediment clouds were also raised by schools of Pacific herring Clupea pallasii, walleye pollock Theragra chalcogramma, and spiny dogfish Squalus acanthias as they encountered the bottom. While these species leave the Inlet during part of the year, repeated ROV surveys (2003 to 2006) indicate that the flatfish populations persist throughout the years. Video and still images from a ROV and a remotely operated in situ camera (Table 1)

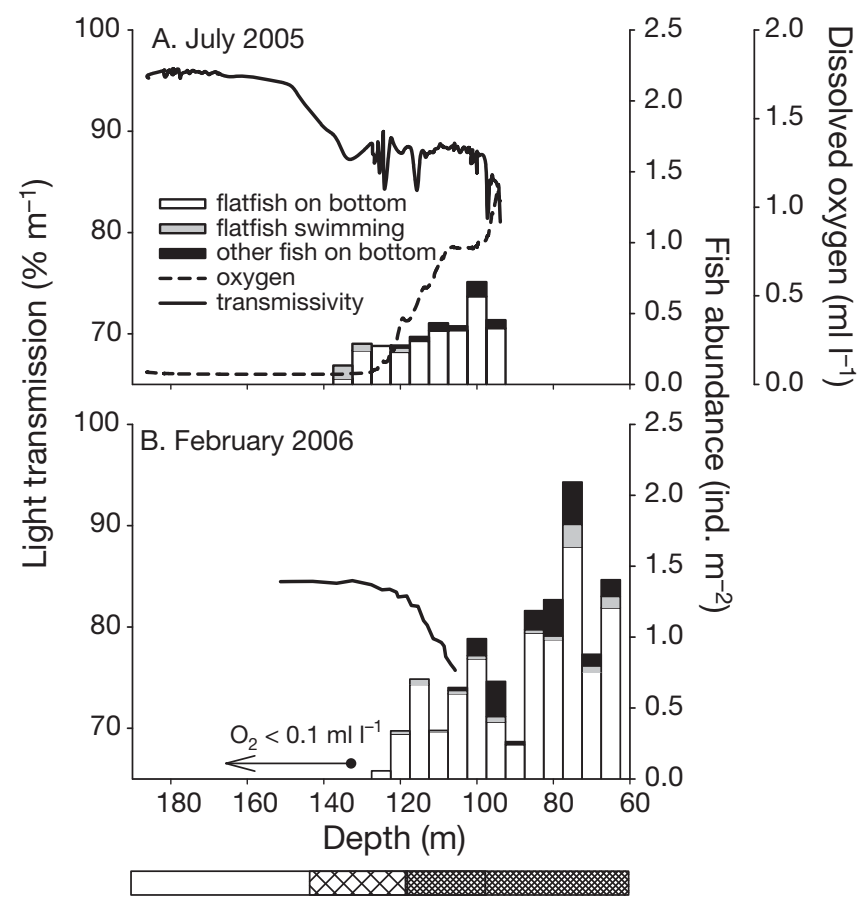

Fig. 5. Fish abundance (bars), oxygen concentration (dashed line), and water turbidity (solid line, measured as \% light transmission) along a near-bottom transect from the anoxic mid inlet to the oxygenated zone of the study site: (A) July 2005, (B) February 2006. Fish distribution was patchy with average CV of $1.1 \pm 0.6$. Visual estimate of bottom disturbance is delineated on the horizontal bar below the $x$-axis: unshaded, intact surface; loosely hatched, $<50 \%$ disturbance; tightly hatched, $>50 \%$ disturbance. The transmissometer malfunctioned for the upper half of this transect but visual estimates suggested higher turbidity at shallower depths

show flatfish lying on, or buried under, the sediment surface in both hypoxic and oxygenated zones (Fig. 2B). In contrast to those in the oxygenated zone, flatfish in the hypoxic zone were occasionally swimming off the bot- 
tom, presumably to feed or possibly increase oxygen uptake. In the combined trawl collections, Lyopsetta exilis was the most abundant species. The $280 \mathrm{~L}$. exilis collected had a standard length of $129 \pm 21 \mathrm{~mm}$, and wet weight of $24 \pm 14 \mathrm{~g}$. Body volume was $24.4 \pm 9.3 \mathrm{~cm}^{3}$ (n = 113), and mean body area was $62 \pm 36 \mathrm{~cm}^{2}$.

\section{Resuspension activity and rate}

The movements of benthic fish during swimming, burial, emergence, and foraging at the sea floor resuspended bottom sediments, forming visible 'sediment clouds' (video clip 1). Three min video clips obtained by the VENUS stationary underwater video camera recorded $27 \pm 42$ resuspension events $\mathrm{m}^{-2} \mathrm{~h}^{-1}$, corresponding to $\sim 650$ events $\mathrm{m}^{-2} \mathrm{~d}^{-1}$ (Tables 1 \& 2). However, most events were small, affecting only the top few mm of sediment. Substantial resuspension events rising over 0.5 mab (corresponding to the spikes in

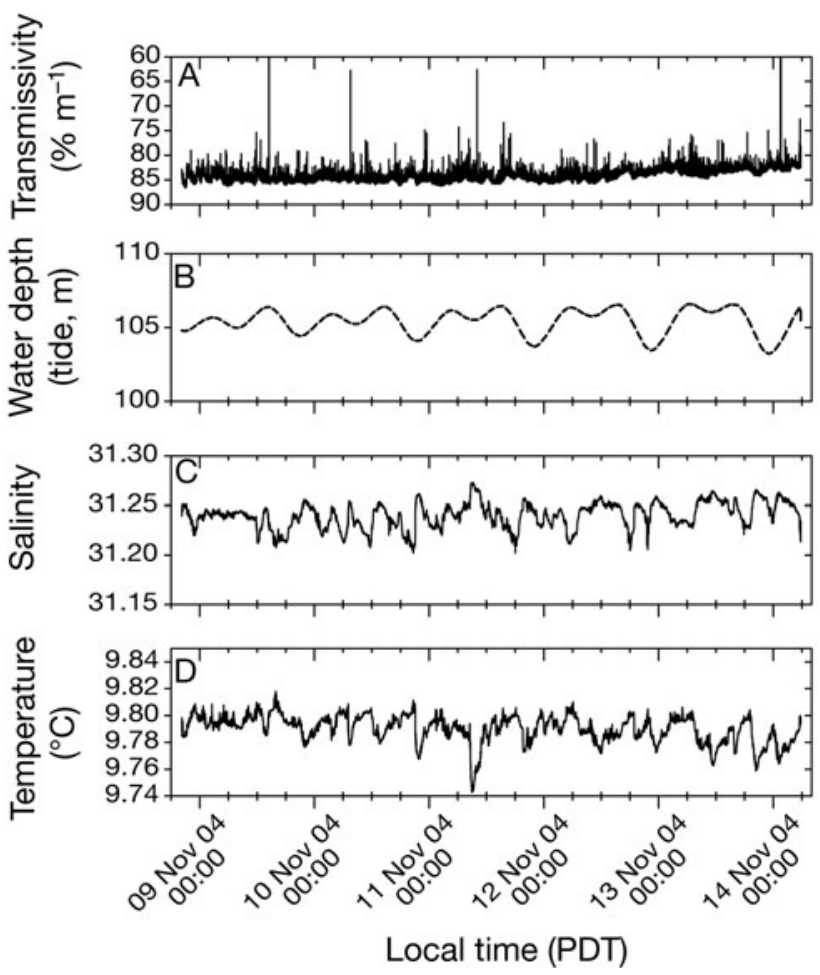

Fig. 6. A typical time series recorded in November 2004 illustrating near-bottom water features at $105 \mathrm{~m}$ depth, $0.5 \mathrm{mab}$ (Table 1). (A) Light transmission with a transmissometer. Note that the $y$-axis scale is reversed so that peaks represent events of elevated turbidity. We interpreted the spikes in light transmission to be brief events of sediment resuspension by fish (see Yahel et al. 2002). For comparison, a flat signal was obtained by this transmissometer during a deployment in a calibration tank with Saanich Inlet sediment but no fish. Marked decreases in transmissivity, surpassing the prediction intervals, were scored as resuspension events (see 'Materials and methods: Statistical analysis'). (B) Water depth illustrating tide phase, (C) salinity, and (D) temperature
Fig. 6A) were usually associated with a flatfish emerging from, or burying into the sediment (video clip 2), thus stirring the sediment to a depth of 1 to $2 \mathrm{~cm}$ or deeper. To quantify the rate of these larger resuspension events, depicted as spikes of decreasing transmissivity in Fig. 6a, we used near-bottom transmissometers and side-looking acoustic doppler current meters (Aquadopp, Table 1). An $11 \mathrm{~d}$ record of these larger resuspension events (95 $\mathrm{m}$ depth, $1 \mathrm{mab}$ ) captured an average of $4.39 \pm 4.29$ and $4.43 \pm 4.33$ events $\mathrm{m}^{-2} \mathrm{~h}^{-1}$ on the 2 horizontal detector beams (Table 2, Fig. 7A; daily average of $107 \pm 42$ events $\mathrm{m}^{-2}$ ). Suspended sediment concentration (approximated by the hourly averaged acoustic backscatter intensity on each beam) was consistently higher on the horizontal beams (11 $\pm 2 \%)$
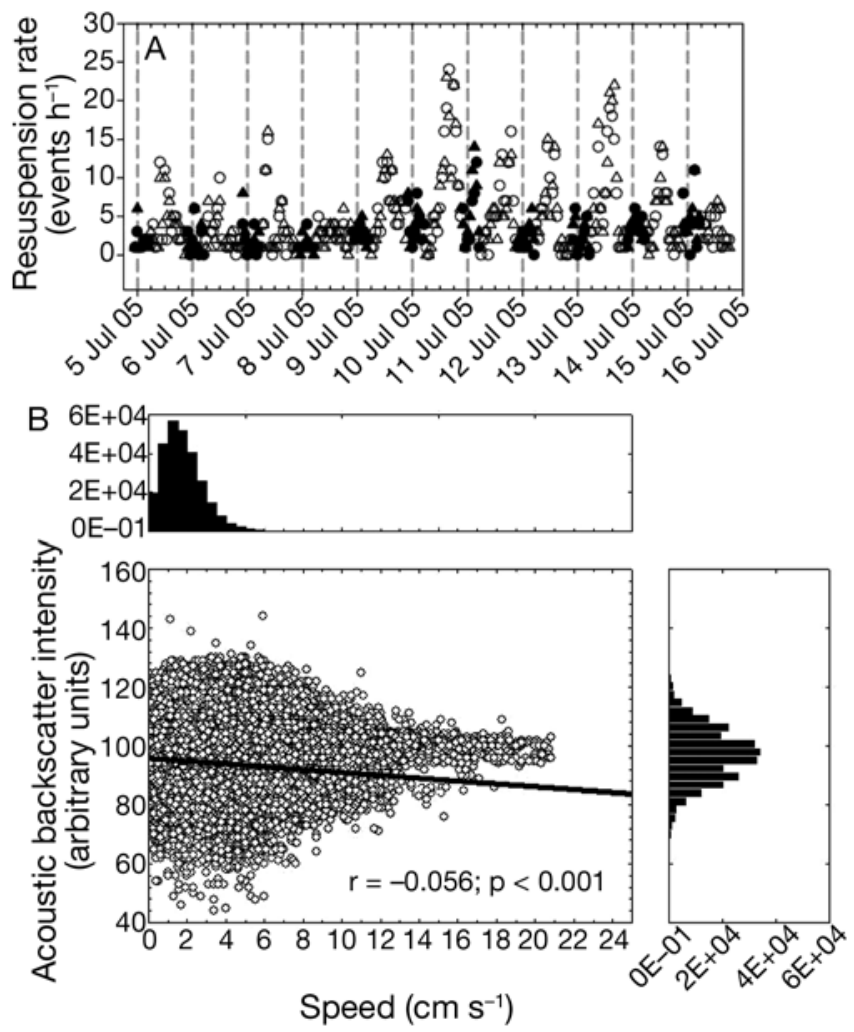

Fig. 7. (A) Hourly rate of larger resuspension events recorded by the 2 beams of an acoustic doppler current meter (Aquadopp) deployed at $95 \mathrm{~m}$ depth on 6-17 July 2005: (O) beam 1, day; $(\mathbf{O})$ beam 1, night; $(\Delta)$ beam 2, day; $(\mathbf{\Lambda})$ beam 2, night. Vertical gridlines mark midnight (local time). Activity peaks normally occurred at daytime, when fish feed on vertically migrating zooplankton. There was no correlation of resuspension rate with tide phases, bottom currents, or deployment duration. (B) Relationship between the average acoustic backscatter (a proxy for suspended sediment concentration) and near-bottom current speed recorded with the VENUS Aquadopp 1 mab over a 12 mo period. Each datum is a $10 \mathrm{~min}$ average for the period 6 February 2007 to 15 July 2007 and $1 \mathrm{~min}$ average for the period 7 September 2007 to 15 March $2008, n=270146$. Frequency distributions of current speed and acoustic backscatter are shown at the top and left sides of the scatter plot, respectively 
Table 2. Rates of sediment resuspension measured by 3 different instruments in Saanich Inlet (Table 1). Transmissometer measured relative water clarity. The Aquadopp is an acoustic current meter that also measured particulate load (as acoustic backscatter). Resuspension events had to reach the detector height to be registered in the instrumental record whereas all resuspension events were counted in the video clips obtained with the camera. mab, meters above bottom. Camera field of view was $1.6 \pm 0.6 \mathrm{~m}^{2}$

\begin{tabular}{|c|c|c|c|c|}
\hline Date & Instrument & $\begin{array}{l}\text { Depth } \\
(\mathrm{m})\end{array}$ & $\begin{array}{c}\text { Sensor } \\
\text { position } \\
\text { (mab) }\end{array}$ & $\begin{array}{c}\text { Resuspension } \\
\text { rate (events } \\
\left.\mathrm{h}^{-1} \mathrm{~m}^{-2}\right)\end{array}$ \\
\hline $\begin{array}{l}6-17 \text { July } \\
2005\end{array}$ & $\begin{array}{l}\text { Aquadopp }{ }^{\mathrm{TM}} \\
\text { transmissometer }\end{array}$ & 95 & $\begin{array}{l}1.0 \\
1.0\end{array}$ & $\begin{array}{l}4 \pm 4 \\
5 \pm 7\end{array}$ \\
\hline $\begin{array}{l}25 \text { April- } \\
21 \text { May } 2006\end{array}$ & $\begin{array}{l}\text { VENUS camera } \\
\text { (remotely controlled) }\end{array}$ & 102 & 1.0 & $27 \pm 42$ \\
\hline $\begin{array}{l}\text { 9-14 November } \\
2004\end{array}$ & Transmissometer & 105 & 0.6 & $6 \pm 7$ \\
\hline $\begin{array}{l}6-17 \text { July } \\
2005\end{array}$ & $\begin{array}{l}\text { Aquadopp } \\
\text { transmissometer }\end{array}$ & 135 & $\begin{array}{c}0.4 \\
<0.1\end{array}$ & $\begin{array}{l}3 \pm 4 \\
6 \pm 9\end{array}$ \\
\hline
\end{tabular}

compared to the third $45^{\circ}$ upward-looking beam of the Aquadopp, indicating that the source of the suspended sediments was at the seafloor. At the deeper nearanoxic site $(135 \mathrm{~m})$, where fish abundance was lower $\left(0.1 \pm 0.3\right.$ fish $\left.\mathrm{m}^{-2}\right)$, the rate of resuspension was lower by $\sim 30 \%$ despite the location of the sensors much closer to the bottom (only $0.4 \mathrm{mab}$ due to sinking; Tables 1 \& 2). Resuspension events were consistently more frequent during daytime $(>60 \%$ of the total; Fig. 7A) when migrating zooplankton concentrated near the seafloor. Simultaneous optical measurements with transmissometers yielded similar resuspension rates and pattern (Table 2).

\section{Nepheloid layers}

ROV transects (sensors at 1 to $2 \mathrm{mab}$ ) from the mid inlet to the study site $(2.8 \mathrm{~km}$; Fig. 1$)$ revealed a positive association between fish abundance, bottom disturbance, and bottom water turbidity (Fig. 5). In addition, water column profiles detected clear water in the bottom $50 \mathrm{~m}$ in the anoxic zone of Saanich Inlet whereas a $20 \mathrm{~m}$ thick nepheloid layer overlay the bottom in oxygenated areas (Fig. 8B). Similar nepheloid layers are mostly ascribed to bottom currents (McCave 1986, Rutgers van der Loeff \& Boudreau 1997). However, the near-bottom current speeds recorded during the observation period $\left(3.6 \pm 2.1 \mathrm{~cm} \mathrm{~s}^{-1}\right.$ at $95 \mathrm{~m}$ depth and $4.2 \pm 2.3 \mathrm{~cm} \mathrm{~s}^{-1}$ at $135 \mathrm{~m}$ depth) are considerably lower than the threshold for silt or clay resuspension (van Rijn 1993).

A link between bottom-water oxygen levels and the presence of a nepheloid layer is also observed in Effingham Inlet on the west coast of Vancouver Island, where bottom currents were $<10 \mathrm{~cm} \mathrm{~s}^{-1}$ (R. Thomson, Institute of Ocean Sciences, pers. comm.). Nearbottom anoxic conditions were associated with clear overlying water and lack of a developed nepheloid layer ( 7 of 8 locations) while oxygenated bottom water had well-developed nepheloid layers (Fig. 9).

\section{Potential effects of fish-induced resuspension}

\section{Benthic oxygen demand}

In vitro simulation of brief sediment resuspension results in a 20 to $30 \mathrm{~min}$ phase of high oxygen demand (Fig. 10; 5 to $13 \mu \mathrm{mol} \mathrm{O} \mathrm{ml}^{-1}$ of resuspended surface sediment). This abrupt oxygen consumption was most likely a consequence of chemical oxidation of reduced species. This phase was followed by a $>24 \mathrm{~h}$ phase of steady oxygen demand (respiration), estimated from the regression of oxygen content in the chamber on incubation times, starting at $1.6 \mathrm{~h}$ after sediment resuspension. Sediment resuspension enhanced benthic oxygen demand by $0.44 \pm 0.04 \mu \mathrm{mol} \mathrm{O} \mathrm{O}^{-1} \mathrm{ml}^{-1}$ of resuspended sediment (Fig. 10; $\mathrm{r}^{2}>0.92$ ). The oxygen de-

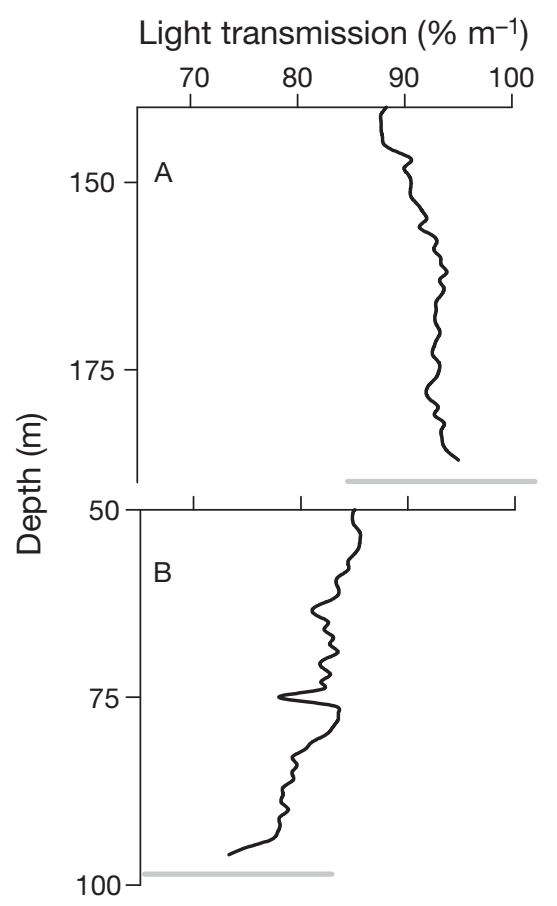

Fig. 8. Typical vertical profiles of light transmission (a proxy for suspended particle concentration) at Saanich Inlet: (A) at the deep near-anoxic (no fish) mid inlet, and (B) at the oxygenated shallow margin densely populated with groundfish (July 2005; start and end of the horizontal transect, respectively; see Fig. 5A). Light grey line indicates sediment surface 


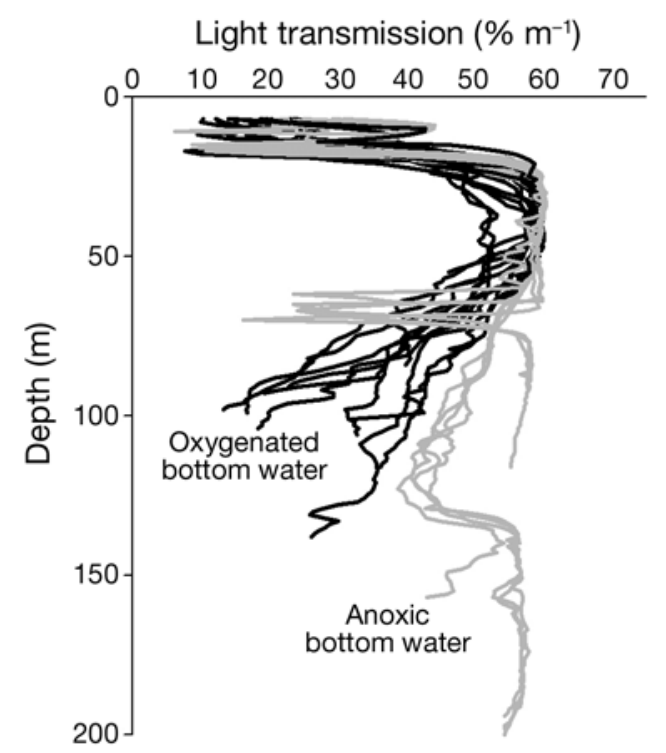

Fig. 9. Vertical profiles of light transmission (a proxy for suspended particles concentration) along a transect beginning at the inner anoxic basin of Effingham Inlet, at the west coast of Vancouver Island (Dallimore et al. 2005). Black lines are profiles $(\mathrm{n}=14)$ taken in locations of oxygenated bottom water where fish would be active $\left(>1.5 \mathrm{ml} \mathrm{DO} \mathrm{l}^{-1}\right.$, profiles end $<10 \mathrm{~m}$ above bottom, bottom currents $<10 \mathrm{~cm} \mathrm{~s}^{-1}$ ), grey lines are profiles taken in regions having anoxic bottom water with no fish $\left(<0.1 \mathrm{ml} \mathrm{DO} l^{-1}\right.$, profiles end $<4 \mathrm{~m}$ above bottom). All profiles were collected on 24 July 2005. A well-developed nepheloid layer was always present over oxygenated bottom water but absent in 7 of the 8 profiles taken over anoxic bottom water. Data courtesy of R. Thomson, Institute of Ocean Sciences, Fisheries and Oceans Canada

mand of undisturbed sediment (in vitro experiments: $64 \mathrm{~cm}^{2}$ cores) was very small and not statistically different from the control (capped cores). ROPOS bottom time limitation allowed only a brief in situ assessment of undisturbed bottom sediments in our benthic chamber before resuspension. The benthic oxygen demand during the undisturbed initial phase of the benthic chamber experiment was $\sim 0.03 \mathrm{nmol} \mathrm{cm}{ }^{-2} \min ^{-1}(0.45 \mathrm{mmol}$ $\left.\mathrm{m}^{-2} \mathrm{~d}^{-1}\right)$. Approximately $5 \mathrm{~min}$ after sediment resuspension, oxygen demand abruptly increased 3.5-fold to $0.11 \mathrm{nmol} \mathrm{cm}^{-2} \mathrm{~min}^{-1}$.

Fish-induced nutrient transport across the sediment-water interface

In situ simulation indicates that brief resuspension is followed by immediate increase in concentrations of ammonium, phosphate, and silicic acid, but not nitrate, (Fig. 11A) in the overlying water; similar tends were observed in in vitro experiments (data not shown). The amount of change in a nutrient after resuspension was related to the initial difference between pore-water

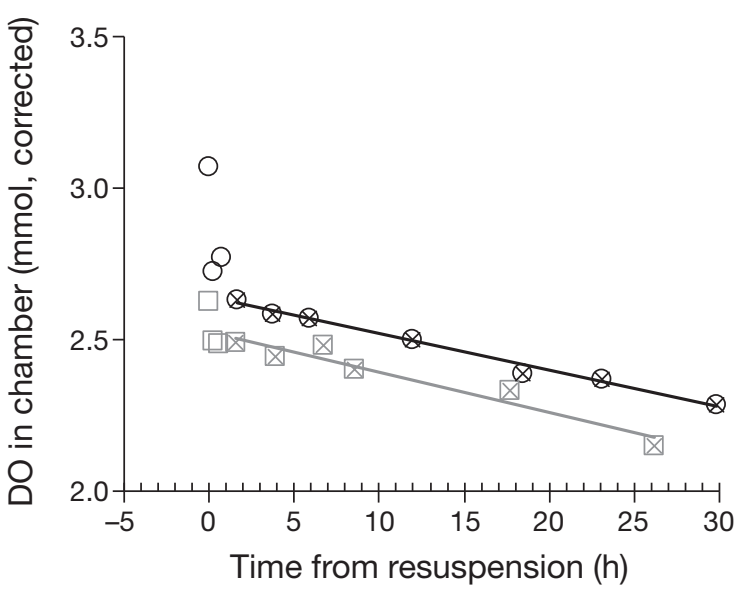

Fig. 10. Dissolved oxygen (DO) content inside a respiration chamber during 2 onboard simulations of surface sediment resuspension: (O) Expt 1, ( $\square$ ) Expt 2. Surface sediment (32 ml) was briefly mixed into the chamber at the beginning of each experiment. The DO content was corrected for the introduction of oxygenated overlying water during sampling (see 'Materials and methods: Simulating resuspension in an onboard incubator'). The chemical oxygen demand (initial oxygen drop) was higher in Expt 1 where surface sediment had higher water content and porosity. Benthic oxygen demand (respiration) was estimated from the regression of oxygen content (corrected for sampling, see text) on incubation time, starting at $1.6 \mathrm{~h}$ after sediment resuspension (symbols marked with $\mathrm{X})$. For Expt 1, $y=2.64-0.012 x, \mathrm{r}^{2}=0.988, \mathrm{p}<0.001$; and for Expt 2, $y=2.53-0.013 x, r^{2}=0.930, p<0.001$

and bottom-water concentrations of that nutrient; Fig. 11B illustrates a linear relationship in which the lack of increase in nitrate reflects the lack of porewater enrichment of this nutrient. The abrupt increases in Fig. 11A are most likely due to mixing of nutrientrich pore-water with the overlying water. Similar results were also obtained in paired water samples taken by the ROV 10 to $20 \mathrm{~cm}$ above fish before, and immediately after, fish movement resuspended sediments (Figs. 3 \& 12, video clip 3).

\section{DISCUSSION}

\section{Fish abundance and behaviour}

Bottom fish rework the sediments in Saanich Inlet extensively and continuously. The abundances of bottom fish recorded here are not abnormally high. Comparable fish densities occur near Kodiak Island, Alaska (Spencer et al. 2005, Stoner et al. 2007) and in various locations along the British Columbia coast (based on shrimp trawl and video surveys; G. Workman, A. Sinclair, Groundfish Division, Fisheries and Oceans, Canada, pers. comm.). Baltz et al. (1993) reported higher densities of benthic fish in a shallow Louisiana estuary. Hagfish (Eptatretus deani and 

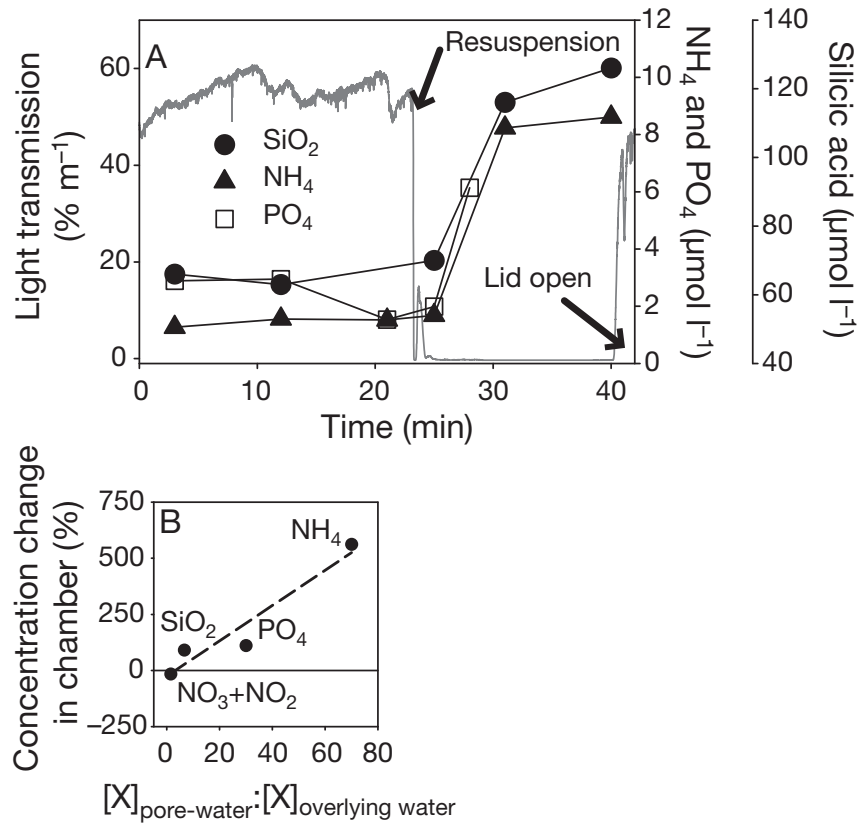

Fig. 11. (A) In situ simulation of a brief sediment resuspension event in a closed benthic chamber (95 m depth, July 2005). Arrows indicate the onset of sediment resuspension by a water jet and termination of the experiment by the opening of the chamber lid. Gray line indicates light transmissivity measured continuously. Nutrient concentrations were measured in discrete water samples taken every few minutes (see 'Materials and methods'). Nitrate concentration $\left(18.2 \mu \mathrm{mol} \mathrm{l}^{-1}\right.$, not shown) varied little $\left( \pm 1.6 \mu \mathrm{mol} \mathrm{l}^{-1}\right)$. (B) Relationship between \% change in nutrient concentration inside the benthic chamber following sediment resuspension and the pre-suspension nutrient concentration ratio between sediment pore water (measured in the upper $2 \mathrm{~cm}$ of a sediment core taken next to the benthic chamber) and the overlying water $\left([\mathrm{X}]_{\text {pore-water }}:[\mathrm{X}]_{\text {overlying water }}\right)$ at the beginning of the experiment. Pearson $r=0.96, p=0.04$

Myxine glutinosa) can also reach high densities (up to 2 ind. $\mathrm{m}^{-2}$ ) off Point Sur, California (Wakefield 1990) and in the Gulf of Maine (Martini et al. 1997). The density of bottom fish (primarily slender sole) at our study site was higher than in some nearby localities (V. Tunnicliffe \& G. Yahel unpubl. data), possibly due to the proximity to the hypoxic zone that may provide food subsidy and/or refuge (e.g. Craig et al. 2004). Fish were often observed emerging from the sediment during the early morning hours to feed on returning vertically migrating zooplankton. This observation supports the description by Pearcy \& Hancock (1978) of Lyopsetta exilis as a planktivore.

\section{Quantification of fish-induced resuspension rate}

To estimate the magnitude of sediment resuspension by fish, we used the resuspension rate measured in the

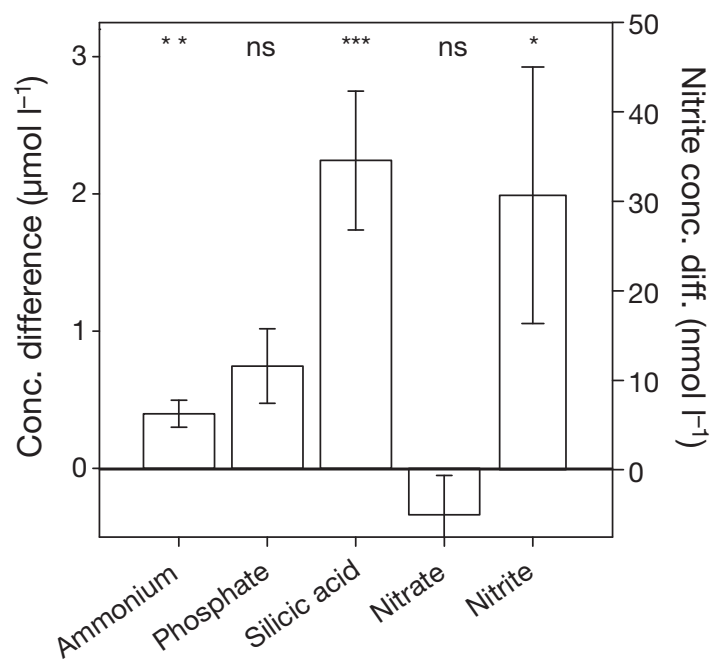

Fig. 12. In situ changes in nutrient concentrations (means \pm $95 \% \mathrm{CI}$ ) following brief fish-induced resuspension events. Bars are average concentration differences in paired water samples $(n=10)$ of near-bottom water before and after a fish created a large sediment cloud (see video clip 3). One-tailed paired $t$-test: ns, no significant difference; ${ }^{*} \mathrm{p}<0.05$; ${ }^{* *} \mathrm{p} \leq 0.01 ;{ }^{* * *} \mathrm{p}<0.001$

acoustic record of the Aquadopp at $95 \mathrm{~m}$ in July 2005 (Table 1) as a representative sample (Fig. 7). Other instruments recorded similar resuspension rates (Table 2). To estimate the area of sediment disturbed by the fish, we conservatively assumed that the large resuspension events recorded by our instrument

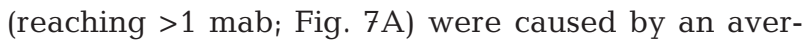
age-sized slender sole suspending its body area without the head, i.e. $\sim 40 \mathrm{~cm}^{2}$ event $^{-1}$. At $107 \pm 42$ resuspension events $\mathrm{m}^{-2} \mathrm{~d}^{-1}$, fish disturbed $0.43 \mathrm{~m}^{2} \mathrm{~d}^{-1}$, i.e. $>40 \%$ of the bottom area is reworked daily. Similarly, if only $12 \mathrm{ml}$ of bulk sediment (half the volume of an average slender sole) were resuspended during each event, the total volume of sediment resuspended daily by fish is $1.3 \pm 0.7 \mathrm{l} \mathrm{m}^{-2} \mathrm{~d}^{-1}$. In this conservative estimate, we did not include the numerous minor resuspension events $\left(>600\right.$ events $\mathrm{m}^{-2} \mathrm{~d}^{-1}$ ) recorded by the VENUS in situ camera.

Thus, where flatfish are present in Saanich Inlet, their activities rework the upper few $\mathrm{cm}$ of the sediment every $2.5 \mathrm{~d}$. In a Red Sea coral reef, a small but active population of bottom-feeding goatfish (Mullidae) resuspended sediment at a similar rate of $>50$ events $\mathrm{m}^{-2} \mathrm{~d}^{-1}$ (Yahel et al. 2002); although the

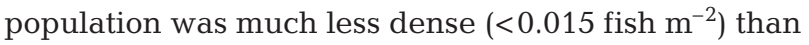
in Saanich, it reworked the bottom every $5 \mathrm{~d}$.

Fish can be attracted to artificial structures such as those in shallow-water reefs (Golani \& Diamant 1999) and oil extraction platforms (reviewed by Vardaro et al. 2007). It is, therefore, possible that our instruments caused artificially higher fish abundance than in adjacent areas without structures. However, no time de- 
pendent trend occurred in any of the hourly resuspension rate time series obtained during our 4 separate instrument deployments spanning 6 to $27 \mathrm{~d}$ (Table 1). Similarly, Vardaro et al. (2007) found no evidence of aggregation or time dependent changes in the abundance of fish in numerous deployments of time-lapse camera systems in the deep North Pacific.

\section{Fish-induced benthic nepheloid layer}

Our findings suggest that fish activity can maintain a BNL. In Saanich Inlet, a near-bottom layer of suspended particles extends up to $20 \mathrm{~m}$ above the oxygenated sediments where benthic fish abound (Fig. 8B). In contrast, water clarity increased towards the bottom of the azoic, anoxic basin (Fig. 8A).

Maintenance of a BNL requires the resuspension of particulates from the sediment to balance the settling of suspended matter. In the ocean, this resuspension is commonly attributed to strong bottom currents or waves (Prandle et al. 2000). However, both wind and tidal forcing of turbulence within Saanich Inlet are generally weak (Gargett et al. 2003) and surface waves have no effect at the studied depths $(>70 \mathrm{~m})$. Currents recorded at this site are lower than the theoretical threshold for resuspension of silt (van Rijn 1993). In experiments with silty sediments similar to those at our site, resuspension was initiated only when currents exceeded a critical velocity of $15 \mathrm{~cm} \mathrm{~s}^{-1}$ at $4 \mathrm{~cm}$ above the bottom (Lansard et al. 2006). Current velocities exceeding $15 \mathrm{~cm} \mathrm{~s}^{-1}$ were never encountered during our field experiments and were rarely $(<0.07 \%$ of the time) encountered during the 12 mo time series depicted in Fig. 7B (average 3.5 and $3.6 \mathrm{~cm} \mathrm{~s}^{-1}$, for Feb-Jul 2007 and Sep 2007-Mar 2008, respectively).

Ruling out physical factors, bottom fish activity is the most likely source of sediment resuspension to the nepheloid layer observed at the oxygenated zone (Figs. 5, 7A \& 8B). Indeed, a sharp increase in turbidity was always associated with the sighting of the first fish across the transition from the deep anoxic basin to the fish populated margins of the Inlet (Figs. $5 \& 8 B$ ). A similar scenario occurs in Effingham Inlet on the west coast of Vancouver Island where bottom currents are $<10 \mathrm{~cm} \mathrm{~s}^{-1}$ (R. Thomson pers. comm.). A welldeveloped BNL was always present in oxygenated bottom water where we assume fish to be active. In contrast, no BNL was detected in the azoic basin nearby where fish would be absent (Fig. 9).

The existence of BNLs where bottom currents are insufficient to initiate sediment resuspension is not limited to enclosed water bodies. Hales et al. (2006) report an unexplainable turbid layer over the bottom near the Oregon coast. Based on our findings and the abundance of groundfish at these localities, we suggest that fish activity may be responsible for maintaining these BNLs.

\section{Potential effects of fish-induced sediment resuspension}

Sediment resuspension by fish is fundamentally different from physical resuspension. Unlike physical resuspension events that are often sporadic and rare below 50 to $70 \mathrm{~m}$ (Danielsson et al. 2007), groundfish activity is a persistent and continuous process (e.g. Figs. 6A \& 7A) (Yahel et al. 2002, Vardaro et al. 2007). Moreover, fish resuspension activity is often brief, localized, and stirs deeper layers of the sediment. Interestingly, a recent study by Stahlberg et al. (2006) showed that short resuspension events (5 s) every 24 to $48 \mathrm{~h}$ enhanced sediment mineralization rate 5 -fold compared to only a 2-fold enhancement measured with continuous resuspension. Thus, the frequency and duration of sediment resuspension by fish reported in our study may maximize organic matter mineralization rate.

To assess the potential effect of fish activity on sediment and mass transport across the water-sediment interface, we conducted a set of preliminary geochemical measurements. Despite the limited nature of these experiments, the results strongly suggest that the ongoing reworking of bottom sediments by fish may have considerable effects on the fate of the organic matter reaching the sediment of productive coastal environments.

\section{Benthic oxygen demand and organic carbon oxidation}

Oxygen fluxes are deemed good proxies for carbon oxidation in both aerobic and anaerobic marine sediments (Canfield et al. 1993, Sarmiento \& Gruber 2006). Therefore, to estimate how fish induced sediment resuspension affects the fate of organic carbon exported from the photic zone to the Inlet floor; we examined oxygen depletion in the water following brief resuspension of sediments (Fig. 10). Considering the first $24 \mathrm{~h}$, we estimated the daily rate of oxygen demand induced by resuspended sediment as $10.2 \pm 1.0 \mathrm{mmol}$ $\mathrm{O}_{2} \mathrm{I}^{-1}$ of suspended sediments. This estimate closely resembles the $\Sigma \mathrm{CO}_{2}$ measurements made by Stahlberg et al. (2006) for short-term resuspension events and is likely to be low as it neglects the brief yet considerable oxygen uptake by reduced chemical species at the beginning of the experiment $\left(6.5\right.$ to $17 \mathrm{mmol} \mathrm{O}_{2} \mathrm{~m}^{-2}$ $\mathrm{d}^{-1}$; Fig. 10). Using our estimate of enhanced oxygen 
demand of 10.2 mmol $\mathrm{O}_{2} \mathrm{l}^{-1}$ bulk sediment resuspended $\mathrm{d}^{-1}$ and the fish induced resuspension rate of $1.3 \pm 0.7 \mathrm{l}$ bulk sediment $\mathrm{m}^{-2} \mathrm{~d}^{-1}$; we can estimate that, in the oxygenated margins of Saanich Inlet, oxygen uptake due to enhanced respiration in resuspended sediments is about $13 \pm 7 \mathrm{mmol} \mathrm{O}_{2} \mathrm{~m}^{-2} \mathrm{~d}^{-1}$. The brief measurement of oxygen demand of undisturbed sediments made with the benthic chamber (25 min) indicated that this demand was small $\left(\sim 0.45 \mathrm{mmol} \mathrm{O} \mathrm{m}^{-2}\right.$ $\mathrm{d}^{-1}$ ). This low rate in undisturbed sediments explains the lack of oxygen drawdown during the control experiments of the onboard incubations.

The dynamics of organic matter remineralization during resuspension and the ratios of oxygen consumed to organic carbon oxidized are not well studied (Stahlberg et al. 2006). Therefore, we conservatively used the canonical 106:150 $\mathrm{C}: \mathrm{O}_{2}$ ratio suggested by Anderson (1995) and calculated an oxidation of $\sim 9 \pm$ $5 \mathrm{mmol} \mathrm{C} \mathrm{m} \mathrm{d}^{-2} \mathrm{~d}^{-1}$ within the suspended sediment fraction. Timothy et al. (2003) measured downward carbon flux of $22 \mathrm{mmol} \mathrm{m}^{-2} \mathrm{~d}^{-1}$ in Saanich Inlet (mean organic carbon fluxes into sediment traps positioned at $45 \mathrm{~m}$ depth). These preliminary calculations suggest that $\sim 40 \%$ of the downward flux of organic carbon exported from surface waters to the oxygenated margins is recycled due to sediment resuspension by fish. Moreover, reworking of the sediment is likely to exhume refractory organic matter and expose it to the overlying oxygenated water thereby enhancing its oxidation rate (Hulthe et al. 1998).

Fish-induced nutrient transport across the sediment-water interface

A major consequence of sediment resuspension by fish is the injection of large quantities of pore water rich in nutrients, dissolved organic matter, and reduced species into the overlying water. This injection results in an immediate increase in nutrient concentration in the benthic boundary layer and a drop in oxygen concentration (Figs. 10, 11A \& 12). Over the subsequent hours to days, the newly injected organic matter plus freshly exposed organic matter in the sediment are oxidized (Fig. 10) and additional nutrients are regenerated and released to the water. While our observations and experiments implicate fish activity in enhancing the regeneration and cycling of nutrients at the sediment-water interface, the quantification of these processes is complicated by redox reactions, sorption processes, and biological uptake.

An estimate of the flux of nitrogen and phosphorus transported by fish across the sediment-water interface can be obtained using our estimate of organic carbon oxidation caused by fish resuspension activity of
$9 \mathrm{mmol} \mathrm{m} \mathrm{m}^{-2} \mathrm{~d}^{-1}$ and the modified RKR ratio (106:16: 1:-150 for $\mathrm{C}: \mathrm{N}: \mathrm{P}: \mathrm{O}_{2}$, respectively; Anderson 1995). Since both $\mathrm{C} / \mathrm{N}$ ratios of the organic matter reaching the sediments (Timothy et al. 2003) and that of the surface sediment are higher than the RKR ratio, we conservatively used the measured $\mathrm{C} / \mathrm{N}$ ratio of 9.3 instead of 6.6 of the RKR. These calculations yield a fish-induced

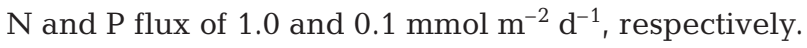
The existence of such flux is supported by the increase in phosphate within the BNL and the 140:1 ratio between the apparent oxygen utilization (AOU) and phosphate increase depicted in Fig. 4.

Further work on opal dissolution in these suspended sediments indicates a substantial recycling of silica by fish activity; phytoplankton productivity in silica-rich taxa such as diatoms may be enhanced by this limiting nutrient (T. Katz unpubl. data).

Respiratory reduction of nitrate (denitrification) is recognized as the most important process converting fixed nitrogen to $\mathrm{N}_{2}$. In current $\mathrm{N}$ cycle models, a major proportion of global marine denitrification (50 to $70 \%$ ) is assumed to take place on the sea floor, particularly in organically rich continental margin sediments (Hulth et al. 2005). Intense denitrification is expected to increase sediment $\mathrm{C} / \mathrm{N}$ ratio. However, the molar $\mathrm{C} / \mathrm{N}$ ratio $(9.3 \pm 0.7)$ of the sediment in our site was similar to or even lower than the $\mathrm{C} / \mathrm{N}$ ratio measured in the particulate matter found in sediment traps (9.2 to 10.4 ; Table 2 in Timothy et al. 2003). The lack of nitrogen depletion of the sediment suggests that the chronic oxygenation of the sediment by fish activity may hamper denitrification processes in the sediment. If sediment resuspension by fish is indeed a global phenomenon, it may help to explain the significantly smaller total $\mathrm{N}$ inputs than estimated fixed $\mathrm{N}$ removal in recent oceanic nitrogen budgets (reviewed by Hulth et al. 2005).

\section{CONCLUSIONS}

Our observations and experiments demonstrate that fish activity can be a major mechanism for sediment resuspension in marine environments and may have important implications for carbon sequestration and benthic oxygen demand. To date, the connection between benthic fish activity and the fate of organic carbon in the seafloor is poorly studied. Based on our findings, and the wide distribution of sedimentresuspending fish in the ocean, we suggest that this phenomenon and its implications to the marine carbon cycle merit further study, especially under productive areas of ocean margins.

In addition, fish resuspension activity likely affects sediment transport, grain sorting, contaminant redistri- 
bution, phytoplankton resting stage dispersal, redox reactions, and diagenetic processes in deep coastal waters. Fish-induced resuspension is an ongoing process; thus, the ability of fish to keep sediment in suspension is likely to enhance lateral transport of settled particles from the continental shelf to the deep sea and may have a notable effect on various global geochemical cycles. In low-energy marine environments (see Boetius et al. 2000, Hales et al. 2006), this activity can influence benthic-pelagic microbial loops, nutrient regeneration, and transport processes. We suggest that, where benthic fish are abundant, their resuspension activity needs to be considered when sediment related processes are discussed.

This study suggests that sediment resuspension activity of benthic fish (and most likely other mobile megafauna) in the ocean plays an important role in cycling carbon and other biogeochemically important elements, sediment transport, and benthic habitat modification. The ongoing decimation of groundfish populations by commercial fisheries and other anthropogenic activities may have far-reaching effects on global biogeochemical cycles.

Acknowledgements. We thank J. M. Rose, D. I. EerkesMedrano, M. van Gurp, I. Beveridge, T. Ingram, F. Whitney, T. Rivlin, M. Drie, and the teams of the Canadian Scientific Submersible Facility (ROPOS), CCGS JP Tully, CCGS Vector, and the VENUS Project for their professional help during field sampling and sample processing. W. Wakefield and R. Thomson provided useful discussions and permission to use their data. The VENUS Project, University of Victoria supported the ship and submersible time for field experiments. Additional funding were provided by NSERC Canada and the Canada Research Chairs Foundation to V.T., a Rothschild fellowship to G.Y., and a Yohay Ben-Nun and Moshe Shilo Minerva Center for Marine Biogeochemistry fellowship to T.K.

\section{LITERATURE CITED}

Aller RC, Aller JY (1998) The effect of biogenic irrigation intensity and solute exchange on diagenetic reaction rates in marine sediments. J Mar Res 56:905-936

Anderson LA (1995) On the hydrogen and cxygen content of marine phytoplankton. Deep-Sea Res I 42:1675-1680

Anderson JJ, Devol AH (1973) Deep water renewal in Saanich Inlet, an intermittently anoxic basin. Estuar Coast Mar Sci 1:1-10

Baltz DM, Rakocinski C, Fleeger JW (1993) Microhabitat sse by marsh-edge fishes in a Louisiana Estuary. Environ Biol Fishes 36:109-126

Berner RA (1980) Early diagenesis: a theoretical approach. Princeton University Press, Princeton, NJ

> Boetius A, Springer B, Petry C (2000) Microbial activity and particulate matter in the benthic nepheloid layer (BNL) of the deep Arabian Sea. Deep-Sea Res II 47:2687-2706

Canfield DE, Jorgensen BB, Fossing H, Glud R and others (1993) Pathways of organic carbon oxidation in three continental margin sediments. Mar Geol 113:27-40

> Craig JF, Halls AS, Barr JJF, Bean CW (2004) The Bangladesh floodplain fisheries. Fish Res 66:271-286
Dallimore A, Thomson RE, Bertram MA (2005) Modern to Late Holocene deposition in an anoxic fjord on the west coast of Canada: implications for regional oceanography, climate and paleoseismic history. Mar Geol 219:47-69

> Danielsson A, Jonsson A, Rahm L (2007) Resuspension patterns in the Baltic proper. J Sea Res 57:257-269

Fuller NJ, West NJ, Marie D, Yallop M, Rivlin T, Post AF, Scanlan DJ (2005) Dynamics of community structure and phosphate status of picocyanobacterial populations in the Gulf of Aqaba, Red Sea. Limnol Oceanogr 50:363-375

Gargett AE, Stucchi D, Whitney F (2003) Physical processes associated with high primary production in Saanich Inlet, British Columbia. Estuar Coast Shelf Sci 56:1141-1156

Golani D, Diamant A (1999) Fish colonization of an artificial reef in the Gulf of Elat, northern Red Sea. Environ Biol Fishes 54:275-282

Gucluer SM, Gross MG (1964) Recent marine sediments in Saanich Inlet, a stagnant marine basin. Limnol Oceanogr 9:358-376

> Hales B, Karp-Boss L, Perlin A, Wheeler PA (2006) Oxygen production and carbon sequestration in an upwelling coastal margin. Global Biogeochem Cycles 20:GB3001

> Hartnett HE, Keil RG, Hedges JI, Devol AH (1998) Influence of oxygen exposure time on organic carbon preservation in continental margin sediments. Nature 391:572-575

Hassan MA, Gottesfeld AS, Montgomery DR, Tunnicliffe JF and others (2008) Salmon-driven bed load transport and bed morphology in mountain streams. Geophys Res Lett 35:04405

> Hedges JI, Keil RG (1995) Sedimentary organic matter preservation: an assessment and speculative synthesis. Mar Chem 49:81-115

Holmes RM, Aminot A, Kerouel R, Hooker BA, Peterson BJ (1999) A simple and precise method for measuring ammonium in marine and freshwater ecosystems. Can J Fish Aquat Sci 56:1801-1808

Hulth S, Aller RC, Canfield DE, Dalsgaard T and others (2005) Nitrogen removal in marine environments: recent findings and future research challenges. Mar Chem 94:125-145

Hulthe G, Hulth S, Hall POJ (1998) Effect of oxygen on degradation rate of refractory and labile organic matter in continental margin sediments. Geochim Cosmochim Acta 62: $1319-1328$

Jorgensen BB (1983) Processes at the sediment water interface. In: Bolin B, Cook RB (eds) The major biogeochemical cycles and their interactions, Vol 21. John Wiley \& Sons, New York, p 477-509

> Lansard B, Grenz C, Charmasson S, Schaaff E, Pinazo C (2006) Potential plutonium remobilisation linked to marine sediment resuspension: first estimates based on flume experiments. J Sea Res 55:74-85

> Lindell D, Post AF (2001) Ecological aspects of ntcA gene expression and its use as an indicator of the nitrogen status of marine Synechococcus spp. Appl Environ Microbiol 67:3340-3349

Martini F, Lesser M, Heiser JB (1997) Ecology of the hagfish, Myxine glutinosa L, in the Gulf of Maine, 2. Potential impact on benthic communities and commercial fisheries. J Exp Mar Biol Ecol 214:97-106

McCave IN (1986) Local and global aspects of the bottom nepheloid layers in the World Ocean. Neth J Sea Res 20:167-181

McCave IN, Hall IR, Antia AN, Chou L and others (2001) Distribution, composition and flux of particulate material over the European margin at $47^{\circ}-50^{\circ} \mathrm{N}$. Deep-Sea Res II 48 : 3107-3139

Meijer ML, Dehaan MW, Breukelaar AW, Buiteveld H (1990) 
Is reduction of the benthivorous fish an important cause of high transparency following biomanipulation in shallow lakes? Hydrobiologia 200-201:303-315

Meysman FJR, Middelburg JJ, Heip CHR (2006) Bioturbation: a fresh look at Darwin's last idea. Trends Ecol Evol 21: 688-695

Nuwer JM, Keil RG (2005) Sedimentary organic matter geochemistry of Clayoquot Sound, Vancouver Island, British Columbia. Limnol Oceanogr 50:1119-1128

Pearcy WG, Hancock D (1978) Feeding habits of Dover sole Microstomus pacificus, Rex sole Glyptocephalus zachirus, slender sole Lyopsetta exilis and Pacific sanddab Citharichthys sordidus, in a region of diverse sediments and bathymetry off Oregon. Fish Bull (Wash DC) 76:641-651

Prandle D, Hargreaves JC, McManus JP, Campbell AR and others (2000) Tide, wave and suspended sediment modelling on an open coast-Holderness. Coast Eng 41:237-267

Redfield AC, Ketchum BH, Richards FA (1963) The influence of organisms on the composition of seawater. In: Hill MN (ed) The sea: ideas and observations on progress in the study of the seas, Vol 2. Interscience Publishers, New York, p 26-77

Sarmiento JL, Gruber N (2006) Ocean biogeochemical dynamics. Princeton University Press, Princeton, NJ

Scheffer M, Portielje R, Zambrano L (2003) Fish facilitate wave resuspension of sediment. Limnol Oceanogr 48:1920-1926

Spencer ML, Stoner AW, Ryer CH, Munk JE (2005) A towed camera sled for estimating abundance of juvenile flatfishes and habitat characteristics: comparison with beam trawls and divers. Estuar Coast Shelf Sci 64:497-503

Stahlberg C, Bastviken D, Svensson BH, Rahm L (2006) Mineralisation of organic matter in coastal sediments at different frequency and duration of resuspension. Estuar Coast Shelf Sci 70:317-325

Stoner AW, Spencer ML, Ryer CH (2007) Flatfish-habitat associations in Alaska nursery grounds: use of continuous video records for multi-scale spatial analysis. J Sea Res 57 : $137-150$

Editorial responsibility: Ronald Kiene,

Mobile, Alabama, USA
Strickland JDH, Parsons TR (1972) A practical handbook of seawater analysis, Vol 167. Fisheries Research Board of Canada, Ottawa

Timothy DA, Soon MYS, Calvert SE (2003) Settling fluxes in Saanich and Jervis Inlets, British Columbia, Canada: sources and seasonal patterns. Prog Oceanogr 59:31-73

Tunnicliffe V (2000) A fine-scale record of 130 years of organic carbon deposition in an anoxic fjord, Saanich Inlet, British Columbia. Limnol Oceanogr 45:1380-1387

Rutgers van der Loeff MMR, Boudreau BP (1997) The effect of resuspension on chemical exchanges at the sedimentwater interface in the deep sea - a modelling and natural radiotracer approach. J Mar Syst 11:305-342

> Rutgers van der Loeff MM, Meyer R, Rudels B, Rachor E (2002) Resuspension and particle transport in the benthic nepheloid layer in and near Fram Strait in relation to faunal abundances and Th-234 depletion. Deep-Sea Res I 49: 1941-1958

van Rijn LC (1993) Principles of sediment transport in rivers, estuaries and coastal seas. Aqua Publications, Amsterdam

Vardaro MF, Parmley D, Smith KL Jr (2007) A study of possible 'reef effects' caused by a long-term time-lapse camera in the deep North Pacific. Deep-Sea Res I 54: 1231-1240

Wakefield WW (1990) Patterns in the distribution of demersal fishes on the upper-continental slope off central California with studies on the role of ontogenetic vertical migration in particle flux. PhD thesis, Scripps Institution of Oceanography, University of California, San Diego

Yahel R, Yahel G, Genin A (2002) Daily cycles of suspended sand at coral reefs: a biological control. Limnol Oceanogr 47:1071-1083

Yahel G, Whitney F, Reiswig HM, Eerkes-Medrano DI, Leys SP (2007) In situ feeding and metabolism of glass sponges (Hexactinellida, Porifera) studied in a deep temperate fjord with a remotely operated submersible. Limnol Oceanogr 52:428-440

Submitted: February 25, 2008; Accepted: August 11, 2008

Proofs received from author(s): November 30, 2008 